\title{
Methylation modification in gastric cancer and approaches to targeted epigenetic therapy (Review)
}

\author{
XIAO-QING ZENG ${ }^{1}$, JIAN WANG ${ }^{1}$ and SHI-YAO CHEN ${ }^{1,2}$ \\ ${ }^{1}$ Department of Gastroenterology, and ${ }^{2}$ Endoscopy Center and Endoscopy Research Institute, \\ Zhongshan Hospital, Fudan University, Shanghai 200032, P.R. China
}

Received January 27, 2017; Accepted March 22, 2017

DOI: 10.3892/ijo.2017.3981

\begin{abstract}
Gastric cancer (GC) is one of the most common cancers and the second leading cause of cancer-related mortality. Increasing discoveries have highlighted aberrant epigetic modifications actively contribute to the pathogenesis of this fatal disease. Among these epigenetic events, dysregulated methylation is particularly associated with GC progression. Importantly, these aberrant methylation modifications caused by the misregulation of methyltranferases are frequently reversible, which provides opportunities for targeted treatment using specific molecular inhibitors. In the present review, we provide an overview of the current literature on the changes of DNA and histone methylations that alter gene expressions in GC and describe the emerging targeted epigenetic therapy in GC.
\end{abstract}

\section{Contents}

1. Introduction

2. Methylation modifications in cancer progression

3. DNA methylation in GC

4. Protein methylation in GC

5. GC-associated HP and EBV infection in modification of methylation

6. Potential therapy targeting changes in methylation

7. Conclusion

\section{Introduction}

Gastric cancer (GC) is the fourth most common cancer and the second leading cause of cancer-related mortality (1). Most

Correspondence to: Dr Shi-Yao Chen, Department of Gastroenterology and Endoscopy Center, Zhongshan Hospital, Fudan University, 180 Fenglin Road, Shanghai 200032, P.R. China

E-mail: chen.shiyao@zs-hospital.sh.cn

Key words: methylation, demethylation, targeted therapy, gastric cancer, epigenetics
GC patients present with advanced-stage disease at the time of diagnosis and have a poor prognosis (2). Genetic and epigenetic aberrations have long been thought to be the two main mechanisms that orchestrate various procedures in the process of GC tumorigenesis. Recent evidence has shown that epigenetic dysregulation plays a crucial role in GC development (3). Among epigenetic alternations, methylation modification is particularly closely associated with GC oncogenesis and progression. These modifications are catalyzed by a class of group-transfer enzymes known as methyltransferases. Although the physiological importance of methylation has been known for many years and has been described in numerous reports, the discovery of enzymes that can reverse methylation has shifted the focus towards the study of methyltransferases, which provides opportunities for targeted treatment using specific inhibitors. The present review highlights the current knowledge of functions of methylation aberrations and may contribute to the understanding of GC mechanisms. We also discuss the importance of methyltransferases and the function of newly emerging molecular inhibitors as anticancer targets in GC.

\section{Methylation modifications in cancer progression}

Epigenetics is formally defined as a heritable and reversible alterations in gene expression or chromosomal stability without changes in the underlying DNA sequence (4). Epigenetic factors help regulate many processes from development to differentiation and are maintained through multiple cellular cycles. In this way, they play a pivotal role in normal development. Abnormalities in the epigenetic control of the normal processes have been increasingly recognized as one of the mechanisms in cancer initiation and progression $(4,5)$.

In normal cells, DNA methylation occurs predominantly in repetitive genomic regions, maintaining genomic integrity while $\mathrm{CpG}$ islands, particularly those associated with promoters, are generally unmethylated. Both hypermethylation and hypomethylation have been observed in all types of cancer cells. Global DNA hypomethylation, particularly in repetitive sequences, plays a vital role across developmental stages and cancer progression. Genome-wide hypomethylation, characterized by the large depletion of methylation, takes place mainly on normally heavily methylated repeat elements such as long interspersed nuclear element (LINE1) 


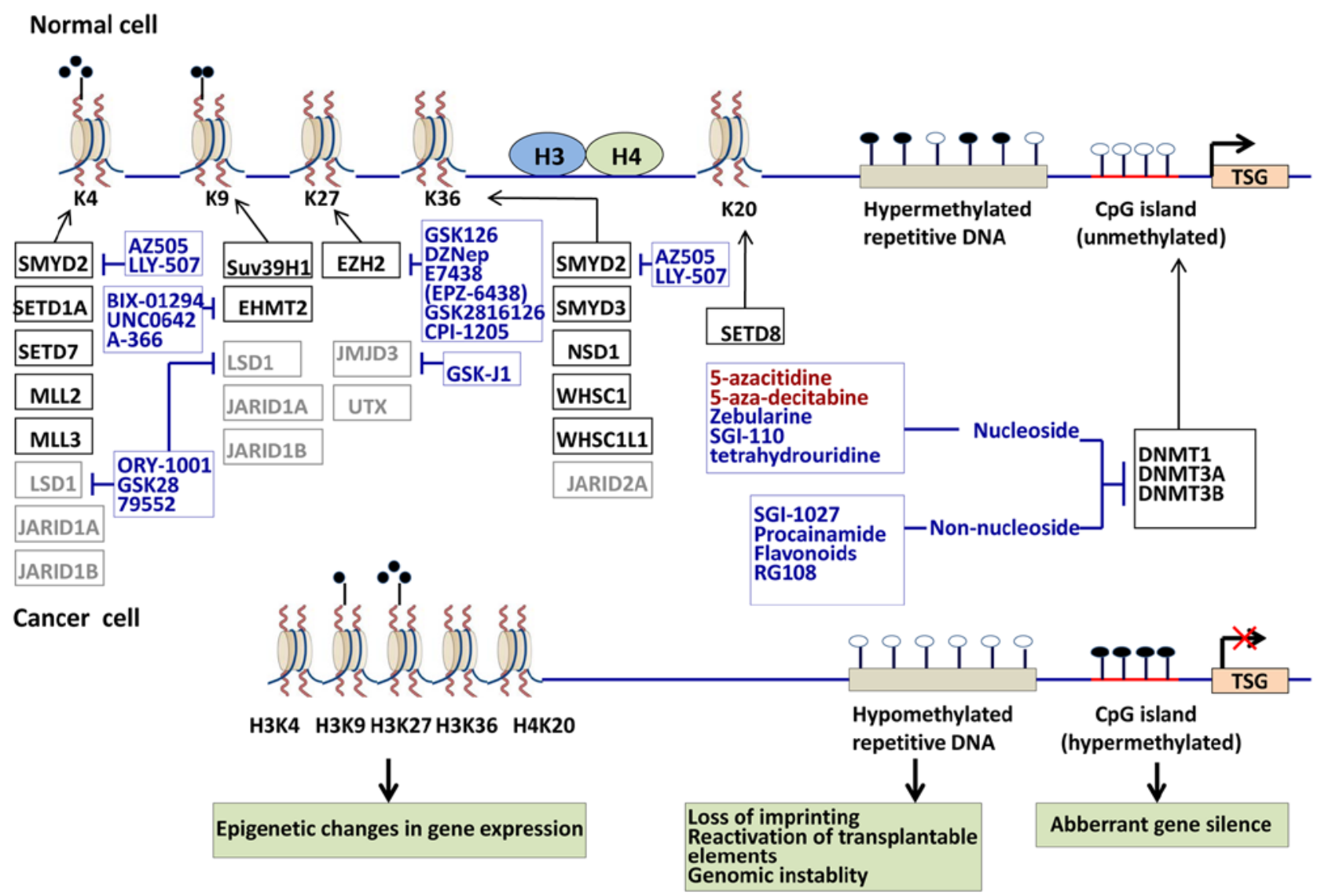

Methylated 9 Unmethylated

Figure 1. Methylation in cancer and the inhibitors. DNA methylation in tumor cells include pronounced CpG-specific hypermethylation in the promoters of tumor suppressor genes (TSG), and generalized hypomethylation of the promoters of oncogenes, regions and repetitive sequences. DNA methylation is mediated by DNMTs. Histone methylation of cancer mainly focused on $\mathrm{H} 3$ and $\mathrm{H} 4$. The modification of histone by methylation, causing nucleosomes to tighten into heterochromatin, is generally associated with gene inactivation or silencing. The most extensively studied histone methylation sites include H3K4, H3K9, H3K27, H3K36, H3K79 and H4K20. Histone methyltransferases and demethylases mediate the addition and removal of methyl groups from different lysine residues on histones. Several agents have been identified as 'capable' of inhibiting the epigenetic processes. Enzymes that control DNA and histone methylation are targets for numerous drugs. TSG, tumor suppressor gene. The red X denotes blockage of TSG expression by DNA methylation. The grey characters represent histone demethylases. The blue characters represent drugs targeting DNA and histone methylation. The red characters represent drugs proved by FDA.

and centromeric satellite repeats (Sat $\alpha$ and Sat2). In general, hypomethylation in cancer cells is associated with a series of adverse outcomes, including chromosome instability (CIN), repression of transposable elements, loss of imprinting (LOI) and activation of oncogenes (6-8). Local hypermethylation of genes takes place on the cytosines located in $\mathrm{CpG}$ dinucleotides resulting in aberrant gene silencing including tumor-suppressor, cell cycle regulator and DNA-repair genes silencing involved in cellular pathways, such as cell cycle, DNA repair, metabolism, cell adherence, apoptosis and angiogenesis $(9,10)$. Diverse tumor types have a diverse region of gene hypermethylation defined as $\mathrm{CpG}$ island methylator phenotype (CIMP). The DNA methylation patterns may be potential prognostic indicators of cancer patients and used as a biomarker (11). DNA methylation is mediated by DNA methyltransferases (DNMTs), which employ S-adenosylmethionine (SAM) to add a methyl group to cytosine residues predominantly in the dinucleotide CpGs $(12,13)$. There are three active DNMTs in mammals: DNMT1, DNMT3A and DNMT3B. DNMT1 is primarily a maintenance methyltransferase, and DNMT3A and DNMT3B are primarily de novo methyltransferases. DNMT1 can interact with both DNMT3a and DNMT3b to influence transcription. In addition, DNMT1 and DNMT3a have both been shown to bind to KMT1A (SUV39H1), a histone methyltransferase (HMT), to mediate repression via $\mathrm{H} 3 \mathrm{~K} 9 \mathrm{me}$ (14). The misregulation of DNA methylation is critical to the initiation and progression of tumorigenesis (Fig. 1) $(4,9)$.

Histone modification is an important epigenetic regulatory process in cancerous tissues and cells. It involves transcription regulation through eight different classes of post-translational modifications, including methylation, acetylation, phosphorylation, ubiquitynation, sumoylation, deamination, proline isomerization and ADP-ribosylation of the core histones $(\mathrm{H} 2 \mathrm{~A}, \mathrm{H} 2 \mathrm{~B}, \mathrm{H} 3$ and H4) $(15,16)$. These modifications are thought to contribute to transcription control through influencing chromatin compactin or signaling to other protein complexes. In normal cells, the promoters of tumor suppressor genes are enriched with active transcription markers, such as $\mathrm{H} 3 \mathrm{~K} 4 \mathrm{me} 3$ and $\mathrm{H} 4$ acetylation, while satellite regions are enriched with repressive markers, such as H3K27me3, H3K9me2 and H4K16Ac. In tumor cells, the promoters of 
Table I. Examples of genes regulated by hyper- or hypo-methylation in GC.

\begin{tabular}{|c|c|c|c|c|}
\hline Functions & $\begin{array}{l}\text { Hypomethylation } \\
\text { gene }\end{array}$ & Ref. & Hypermethylation gene & Ref. \\
\hline Cell cycle & - & - & $\begin{array}{l}\text { PRDM5, TCF } 4, \mathrm{p} 16^{\mathrm{INK} 4 \mathrm{a}} \\
\text { CDKN2B/p15 } \\
\text { INK2b } \\
\text { p } 14^{\mathrm{ARF}}\end{array}$ & $(29-31)$ \\
\hline DNA damage repair & - & - & hMLH1, MGMT & $(32,33)$ \\
\hline Signal transduction & - & - & $\begin{array}{l}\text { RASSF1A, SFRP5, CTNNB1, SOCS-1, RAR } \beta \text {, } \\
\text { Dkk-3, ZNF545 }\end{array}$ & $(34-41)$ \\
\hline Adhesion and invasion & R-RAS & $(42)$ & $\begin{array}{l}\text { APC, E-cadherin (CDH1), H-cadherin (CDH13), } \\
\text { TSP-1, PLA2G2A }\end{array}$ & $(43-45)$ \\
\hline Apoptosis & - & - & BNIP3, DAPK, PCDH10, PCDH17, SFRP2, BCL6B & $(34,46-51)$ \\
\hline Autophagy & - & - & PCDH17, klotho & $(48,52)$ \\
\hline Cell growth/differentiation & ASCL2 & $(53)$ & & \\
\hline
\end{tabular}

tumor suppressor genes lose nearly all acetylation and acquire repressive markers including $\mathrm{H} 3 \mathrm{~K} 27 \mathrm{me} 3$ and $\mathrm{H} 3 \mathrm{~K} 9 \mathrm{me}$. Repressive markers such as $\mathrm{H} 4 \mathrm{~K} 20 \mathrm{me} 3$ and $\mathrm{H} 3 \mathrm{~K} 27 \mathrm{me} 3$ are lost at repetitive satellite regions leading to $\mathrm{CIN} / \mathrm{microsatel}$ lite instability (MSI) (Fig. 1). Acetylation and methylation of histone lysine residues are the most thoroughly studied histone profiles. Typically, histone acetylation is associated with an active transcription, whereas methylation may be associated with either active or repressive states, depending on the target amino acid residues and the range of methylation (me1, me2 or me3) (17). A possible explanation is that histone methylation does not only alter the charge on the histone tails but also influences the basicity and affinity of different reader proteins to the methylated sites. Generally, H3K4, H3K36 and H3K79 methylations are associated with active genes while $\mathrm{H} 3 \mathrm{~K} 9$, H3K 27 and H4K20 methylations are considered repressive markers leading to inactive genes.

Epigenetic modifications are not standalone processes, instead, are subject to considerable crosstalk among the different types of epigenetic markers. Research in model organisms has shown that there are extensive links and crosstalk between histone modifications and DNA methylation. Key to these links are the readers of histone methylation including plant homeodomains (PHDs), chromodomains and bromo adjacent homology domains (BAH domains) and readers of DNA methylation such as the SRA (SET- and RING-associated), CXXC domain and methyl-CpG-binding domain (MBD). The unifying molecular feature of $\mathrm{GC}$ is a profoundly reshaped epigenome characterized by global genomic hypomethylation, gene-specific DNA hyper- or hypo-methylation, aberrant expression of DNMTs and histone methylation enzymes (18).

\section{DNA methylation in GC}

Global DNA hypomethylation. Global DNA hypomethylation is mostly seen in GC (19-21), even at the early steps of carcinogenesis $(22,23)$. An enhanced hypomethylation was associated with a more invasive and advanced stage type of GC (23). Previous studies have shown that global DNA hypomethylation accumulates with patient age and is associated with copy number alterations in gastrointestinal cancers, possibly due to gradual acquisition of aberrance during DNA methylation and correlates to genomic damage (23). LINE-1 is frequently hypo-methylated in GC (24) and is associated with poor prognosis (25). Moreover, LINE-1 hypomethylation in GC patients is significantly correlated with HP infection (24). Hypomethylation of Alu elements, a member of the short interspersed nuclear element (SINE) family of repetitive elements, was also observed in GC (26). Alu and Sat $\alpha$ hypomethylation is induced in gastric mucosae by $H$. pylori infection during gastric carcinogenesis (21). LOI is another example of an epigenetic alteration related to aberrant hypomethylation (21). LOI of the insulin-like growth factor-2 gene (IGF2) was shown to be associated with increased GC risks $(21,27)$.

Cancer-linked gene-specific DNA hyper- and hypo-methylation. Regions of lower-density methylation near $\mathrm{CpG}$ islands (CGIs), defined as 'shores', exhibit great variation in methylation, including hypomethylation and hypermethylation, across diverse types of cancers (28). Currently, a number of hypomethylated tumor-promoting genes and hypermethylated tumor-suppressor genes (TSG) have also been found in GC and are associated with oncogene positive transcriptional regulation during a variety of cellular processes (Table I). The DNA methylation of chromatin-modifying enzymes (CMEs) that cause changes in chromatin structure can affect diverse pathways involved in multiple aspects of GC development and progression. For example, SMARCA5 and MGMT (O-6-methylguanine-DNA methyltransferase), SWI/SNF related, are downregulated in GC as a consequence of its promoter methylation $(54,55)$. The methylation HLTF, encoding a member of the SWI/SNF family, has been reported in $50 \%$ of cases of GC (56). DNA methylation biomarkers of certain genes that are abnormally repressed in GC are appealing in normal gastric epithelium or premalignant lesions as well as in other body samples (e.g. stool and plasma) early in GC development. Alterations in DNA methylation can also influence treatment response in GC. For example, methylation of SULF2 and BMP4 have been linked to chemotherapeutic responses $(57,58)$.

GC-associated alterations in DNA methylation were widespread and tend to localize at CGIs (59). Patients with 
Table II. Histone methyltransferases and functions in GC.

\begin{tabular}{|c|c|c|c|c|}
\hline Enzymes (alias) & $\mathrm{GC}$ & Target gene & Gene function & Ref. \\
\hline SMYD2 (KMT3C) & Up & ND & ND & (84) \\
\hline SMYD3 (KMT3E) & Up & ND & ND & $(85-88)$ \\
\hline Suv39H1 (KMT1B) & Up & BCL-2, pro-caspase-9, pro-caspase-3, C-myc & Apoptosis, proliferation & (89) \\
\hline EZH2 (KMT6) & Up & $\begin{array}{l}\text { RUX3, ANX46, } \\
\text { E-cadherin, ArgBP2, } \\
\text { p53, p21, p14, p16, } \\
\text { CXXC4 }\end{array}$ & $\begin{array}{l}\text { Proliferation } \\
\text { Invasion, migration } \\
\text { Cell cycle } \\
\text { Signal transduction }\end{array}$ & $\begin{array}{l}(90,91) \\
(92,93) \\
(94,95) \\
(96,97)\end{array}$ \\
\hline SETD7 & Down & SREK1IP1, PGC, CCDC28B & Proliferation, migration, invasion & (98) \\
\hline $\begin{array}{l}\text { JARID1A } \\
\text { (KDM5A/RBP2) }\end{array}$ & $\mathrm{Up}$ & $\mathrm{p} 21^{\mathrm{CIP} 1}, \mathrm{p} 27^{\mathrm{kip} 1}, \mathrm{p} 16^{\mathrm{ink} 4 \mathrm{a}}$ & Senescence/cell growth & (99) \\
\hline JARID1B (KDM5B) & Up & ND & ND & $(100)$ \\
\hline LSD1 (KDM1A) & Up & $\begin{array}{l}\text { TGF- } \beta 1 \text {, VEGF, Bcl- } 2, \beta \text {-catenin, p-ERK, } \\
\text { p-Smad } 2 / 3\end{array}$ & Proliferation, invasion, apoptosis & $(101)$ \\
\hline JMJD1A (KDM3A) & Up & ND & ND & (102) \\
\hline JMJD2A (KDM4A) & Up & ND & ND & (103) \\
\hline JMJD2B (KDM4B) & Up & $\mathrm{p} 53, \mathrm{p} 21^{\mathrm{CIP} 1}$, vimentin & $\begin{array}{l}\text { DNA repair } \\
\text { Proliferation, apoptosis } \\
\text { EMT }\end{array}$ & $\begin{array}{l}(104) \\
(104) \\
(105)\end{array}$ \\
\hline
\end{tabular}

ND, not determinated.

widespread gene hypermethylation tend to have poor overall survival (59). However, the methylation profile differs between the intestinal and diffuse types of GC (60). The epithelial cadherin gene CDH1, a tumor suppressor gene which is downregulated in gastric tumors, is hypermethylated more frequently in the diffuse type of GC than in the intestinal type $(61,62)$. Zouridis et al (59) showed that patients with CIMP-positive GC tend to be younger, with less-differentiated tumors, and their cases are associated with diffuse histology and tend to exhibit worse survival outcomes. One potent cause is that genes methylated by CIMP in GC overlap with those corresponding to PRC2-targets in embryonic stem cells, suggesting that it has been present since normal, early development. The strong relationship between CIMP and H. pylori, EBV, and MSI has been emphasized in a meta-analysis, but CIMP cannot be used as a prognostic marker for GC (63).

DNA methyltrasferases. Notably, the increased expression of DNMT3A in GC is significantly higher than that of DNMT1 and DNMT3B $(64,65)$. A recent study demonstrated that the poor overall survival rate of GC patients is associated with elevated DNMT3A expression, but not with increased expression of DNMT1 or DNMT3B (66). DNMT3A contributes to the dysregulation of the cell cycle by repressing $\mathrm{p} 18^{\mathrm{INK} 4 \mathrm{C}}$ in a DNA methylation-dependent manner (67). DNA methyltransferase genes have been shown to be mutated in certain cancers. For example, the DNMT3A gene is mutated in acute myelogenous leukemia, myeloproliferative disease and myelodysplastic syndrome (68). Zang et al (69) also observed that GC had mutations in DNMT3A $(1 / 15 ; 6.7 \%)$. In addition,
$23.5 \%$ allelic loss of DNMT3A was observed in GC (70). Increment of functional polymorphism of DNMT1, DNMT3A and DNMT3B were found in gastric neoplasm and have been found to be associated with development and progression of GC (65,71-73). One meta-analysis showed that DNMT1 rs16999593 and DNMT3A rs1550117 could result in GC and that DNMT3B rs1569686 may be a protective factor against gastric carcinogenesis (73). Furthermore, DNMT1, DNMT3A and DNMT3B proteins are downregulated through overexpression of miR-200b and miR-200c, resulting in the global DNA hypomethylation in GC cell lines (74). In addition, H. pylori infection could increase DNMT activity via upregulation of the epidermal growth factor (EGF) and its receptor or via the release of inflammatory mediators, such as NO $(75,76)$. In particular, overexpression of DNMT1 and DNMT3b was found to be associated with EBV infection in GC (77,78).

\section{Protein methylation in GC}

Histone methylation and HMT. Studies conducted on histone methylation of GC have focused mainly on $\mathrm{H} 3$ and H4 $(56,79)$. Studies have reported that certain histone methylation markers ( $\mathrm{H} 3 \mathrm{~K} 4 \mathrm{me} 3, \mathrm{H} 3 \mathrm{~K} 9 \mathrm{me} 3$ and $\mathrm{H} 3 \mathrm{~K} 27 \mathrm{me} 3)$ are positively correlated with clinicopathological characteristics in GC, including tumor stage and survival (80-83). As a sequence, specific histone methylation can result in dysregulation of many genes with important roles in GC (Table II). For instance, EZH2 mediates H3K27 trimethylation to maintain transcriptional silencing. EZH2 knockdown represses cell growth, cell proliferation (RUX3 and ANXA6) $(90,91)$, 


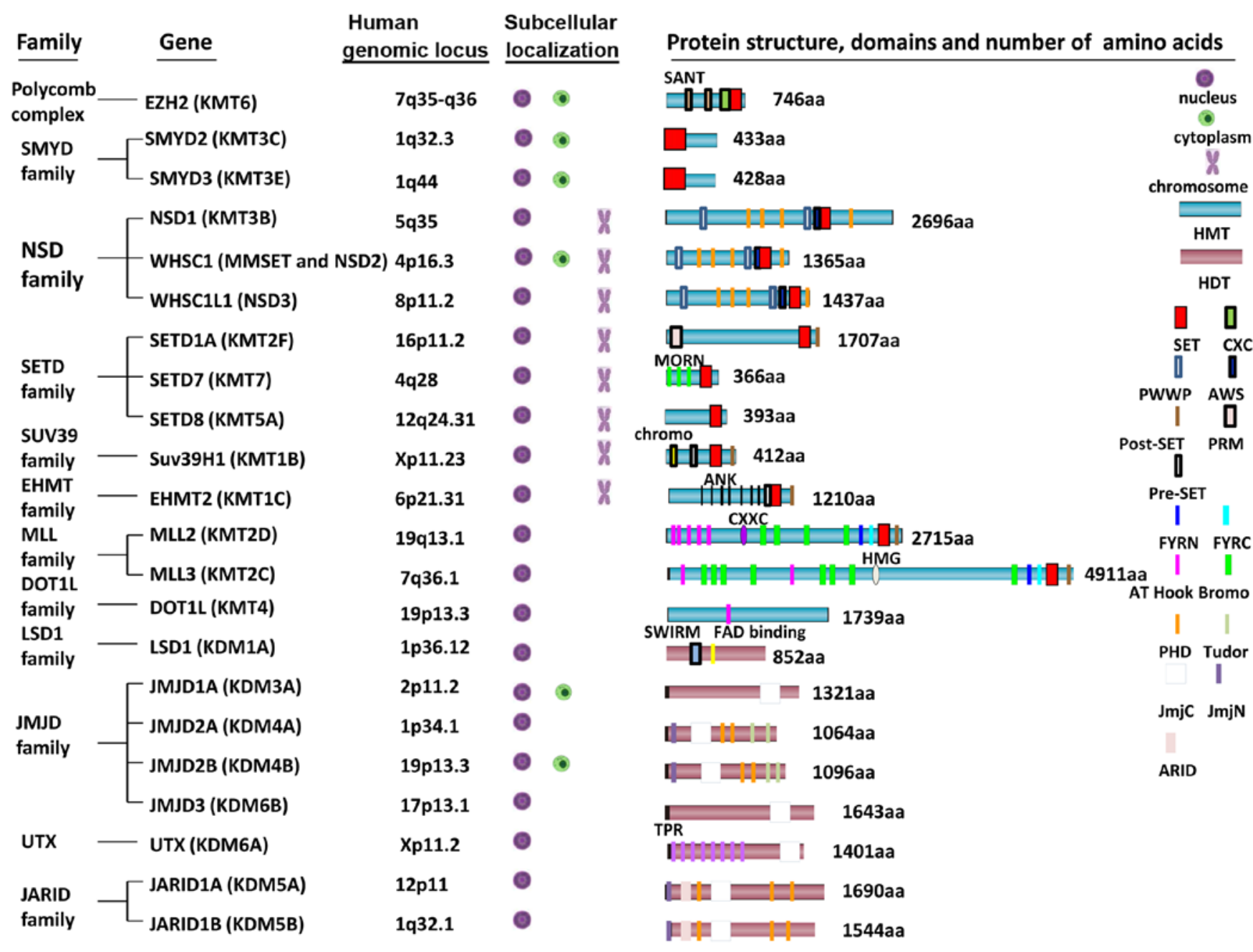

Figure 2. The gene, subcellular localization and protein structure of some histone methyltransferases.

invasion and migration (E-cadherin and $\operatorname{ArgBP} 2)(92,93)$, and induces cell cycle arrest in GC cells (p53, p21, p14 and p16) $(94,95)$. In addition, EZH2 promotes the activation of Wnt and MAPK signaling through downregulation of CXXC4 expression, figuring an epigenetic mechanism of wnt signaling activation in GC cells $(96,97)$.

Histone methylation is processed by lysine methyltransferases. A number of HMTs and histone demethylases (HDTs) have been found to mediate the addition and removal of methyl groups from different lysine residues on histones. Indeed, methylation at different lysine residues on histones has been shown to display differential functions (69). A current model suggests that methylated histones are recognized by chromatin effector molecules (readers), leading to the recruitment of other molecules to alter the chromatin and/or transcription states (106). In particular, histone methylation reader proteins such as WD40 repeats, chromo- and bromodomain proteins, and the PHD finger domain were shown to recruit HMTs to their target sites. During the past decade, several HMTs and HDTs have been identified in humans (Fig. 2). All HMTs except KMT4 (DOT1L), contain the SET-domain, which provides interaction and recognition sites for lysine substrates and cofactors for general catalysis. SET-domain-containing protein, a class of HMTs, has been regarded as an important factor in carcinogenesis (107). HDTs include amine oxidaselike (AOL) domain-containing demethylases and Jumonji C (JmjC) domain-containing demethylases $(108,109)$. These HMTs and HDTs have been shown to methylate histones incorporated in chromatin, free histones and non-histone proteins (110).

Non-histone methylation. Beyond alteration of the histone code, HMT interacts with various molecules including DNMT1. For example, EZH2 can recruit and regulate other epigenetic silencing enzymes, such as DNMTs, by influencing the binding capacity between DNMTs and the promoter of target genes (111). DNMT1-mediated promoter methylation is indispensably maintained by EZH2-mediated methylation $(112,113)$. LSD family members contain a SWIRM domain and an AOL domain. The SWIRM domain is present in many chromatin-interacting enzymes and it can interact with DNA. Several studies have shown that the expression of several genes in GC can be regulated by DNA methylation and histone modification simultaneously $(83,114,115)$. For example, gene expression of PRDM5 (PR domain containing 5), a member of the kruppel-like zinc finger family, is downregulated via DNA methylation and $\mathrm{H} 3 \mathrm{~K} 27$ trimethylation, alleviating the cell-growth-suppressive effect of PRDM5 (116). 
The biological and physiological significance of nonhistone lysine methylation in human tumorigenesis has been recently explored $(117,118)$. For example, SET and MYND domain-containing protein 2 (SMYD2) was identified as a lysine methyltransferase for K370 of p53 (119), K860 and $\mathrm{K} 810$ of Rb $(120,121)$ and K528 of PARP1 (122). SMYD2dependent methylation of $\mathrm{Rb}$ at $\mathrm{K} 810$ promotes the cell cycle progression of cancer cells (121). Moreover, methylation of K528 on PARP1 enhances its poly(ADP-ribose) activity in cancer cells (122). Mazur and colleagues (123) found that SMYD3 methylated the lysine 260 of MAP3K2 gene, leading to the activation of the signaling of the Ras/Raf/MEK/ERK in the development of pancreatic ductal adenocarcinoma and lung adenocarcinoma.

\section{GC-associated HP and EBV infection in modification of methylation}

Inflammation can predispose tissues to cancer, and it is very likely that DNA methylation is involved in this process (124). The stomach has been described as the organ with the highest $\mathrm{CpG}$ island hypermethylation frequency which is ageassociated and possibly inflammation-mediated (29). From an etiological viewpoint, two pathogens, H. pylori (HP) and Epstein-Barr virus (EBV), are known to participate in gastric carcinogenesis. Chronic inflammation in the gastric mucosa due to HP and EBV infection of gastric epithelial cells has been reported to cause aberrant promoter methylation, which may contribute to the tumorigenic mechanisms of these pathogens.

In the multistep development of gastric carcinogenesis, chronic HP infection progresses over decades, through stages of chronic gastritis, atrophy, intestinal metaplasia, adenoma/ dysplasia and cancer. Moreover, global DNA hypomethylation might be implicated in GC associated with HP infection during early stages (125). According to a study that investigated the promoters of 48 genes in the gastric mucosae with or without HP infection, results suggest a possible link between aberrant DNA methylation and HP infection (126). Furthermore, some of these HP-related events (such as hypermethylation) are reversed after HP eradication. However, in patients with preneoplastic lesions, global DNA methylation decreased over time despite eradication of HP infection (125).

HP can induce methylation of multiple $\mathrm{CpG}$ islands, especially at sites encoding tumor suppressors such as E-cadherin, MGMT and the eradication has led to a marked decrease in methylation levels of these genes (127). Inflammation triggered by HP infection can induce aberrant DNA methylation, which appears to be a critical process (128). HP may induce aberrant DNA methylation through the release of ROS and nitric oxide (NO) and the activation of DNMT (129). Apart from DNA methylation, HP also regulates histone modifications in human gastric epithelial cells through the ROS and histone methyltransferase. For example, Angrisano et al (130) reported that HP infection is followed by activation of iNOS gene expression, chromatin changes at the iNOS promoter (including decreased $\mathrm{H} 3 \mathrm{~K} 9$ methylation and increased $\mathrm{H} 3 \mathrm{~K} 4$ methylation), and selective release of MBD2 from the iNOS promoter in a GC cell line. $\beta$-catenin directly binds to JMJD2B (KDM4B) promoter and stimulates JMJD2B expression after
HP infection. Increased JMJD2B, together with NF- $\mathrm{BB}$, binds to COX-2 promoter to enhance its transcription by demethylating H3K9me3 locally (131).

$\mathrm{EBV}^{+} \mathrm{GC}$ forms a distinct subgroup of GC and exhibits exceptionally high DNA methylation levels, surpassing even CIMP tumors, as described by earlier studies and confirmed by TCGA $(132,133)$. One possible reason is that such hypermethylation may represent a cellular reaction to viral infection. As supported in a previous study, EBV infection can regulate the expression of a panel of genes through promoter methylation, including MINT, TIMP-3, CDH1, p16, ACSS1, FAM3B, IHH and TRABD in GCs $(78,134,135)$. EBV infection-induced hypermethylation of a specific group of silencing genes may favor malignant transformation during development of this unique subtype of GC (136). Such methylation epigenotypes are not a parallel phenomenon to EBV infection but rather caused by the EBV infection itself (133). Matsusaka et al (137) classified GC into three epigenotypes, EBV-/low methylation, $\mathrm{EBV}^{-} /$high methylation and $\mathrm{EBV}^{+} /$high methylation, according to the pattern of DNA methylation. EBV-positive GCs exhibited distinct and markedly high levels of methylation (e.g. CXXC4, TIMP2 and PLXND1).

\section{Potential therapy targeting changes in methylation}

Taking into account the reversibility of epigenetic modification, a new field of therapy focusing on key targets, known as pharmocoepigenomics, has been developed to either block or reverse the aberrant epigenetic modifications at an early stage (138). Compounds in preclinical and clinical stages reported in cancer are summarized in Fig. 1. The present review describes drugs targeting disordered patterns of DNA and histone methylation and their potential efficacy in GC (Table III).

Inhibitors of DNMTs (DNMTi). As mentioned above, it has been well established that many genes are hypermethylated in GC (Table I). Two DNA methylation inhibitors, azacytidine (5-azacitidine) and decitabine (5-aza-deoxycytidine) have been established for the treatment of myeloid malignancies $(145,146)$. Recently, more and more DNMT inhibitors, categorized as nucleoside analogs (decitabine, zebularine, SGI-110 and tetrahydrouridine) and non-nucleoside compounds (SGI-1027, procainamide, flavonoids, RG108 and their derivatives), are actively being explored in the clinical and preclinical trials as novel treatments for cancer (Fig. 1) (147).

Azacytidine and decitabine. Azacytidine and decitabine are nucleoside analogs of cytosine that cannot accept a methyl donor at the 5' position of the pyrimidine ring and depletes cellular DNMT1. Intracellularly, azacytidine can convert to decitabine and subsequently be incorporated into DNA (148). Results showed that azacitidine inhibited the proliferation and decreased the level of DNA methylation in GC cell lines (149). Decitabine treatment resulted in growth suppression and reduced the levels of DNMT3A and DNMT3B accompanied with the demethylation of P16 ${ }^{\text {INK4A }}$ gene (140). CIMP-positive GC lines appeared to exhibit significant reductions in proliferation after treatment of DNMT inhibitors such as decitabine compared to non-CIMP lines (59). The greatest challenge 
Table III. Summary of inhibitors targeting the methylation modification in GC.

\begin{tabular}{|c|c|c|c|c|c|}
\hline Targets & Compound & Chemical nature & Mechanism of action & Stage & Ref. \\
\hline \multicolumn{6}{|l|}{ DNMT } \\
\hline & Vidaza & 5-azacitidine & $\begin{array}{l}\text { Irreversible covalent link with the enzyme } \\
\text { leading to a cellular DNMT depletion }\end{array}$ & Clinical & $(139)$ \\
\hline & Decitabine & 5-aza-deoxycytidine & Inhibition of DNMTs & Preclinical & $(140,141)$ \\
\hline & Zebularine & 2(1H)-pyrimidinone riboside & Inhibition of DNMT and cytidine deaminase & Preclinical & $(142)$ \\
\hline \multicolumn{6}{|l|}{ HMT } \\
\hline \multirow[t]{2}{*}{$\mathrm{EZH} 2$} & GSK126 & a & SAM-competitive inhibitor of PRC2 & Preclinical & $(143)$ \\
\hline & DZNep & 3-deazaneplanocin A & SAH hydrolase inhibitor of methyltransferases & Preclinical & $(144)$ \\
\hline
\end{tabular}

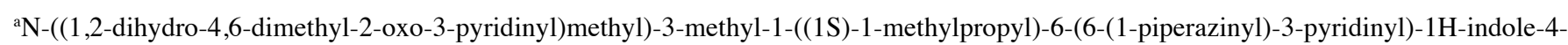
carboxamide.

associated with decitabine is the compound's instability, which limits its efficacy in treating solid tumors (150).

A recent experimental study showed that the treatment of DNMT inhibitors alone may be inadequate to reactivate gene expression (151). Neither azacytidine nor decitabine has been established as a single-agent therapy for GC in clinical settings. However, there is evidence that DNMT inhibitors can increase chemosensitization when combined with traditional chemotherapy because the reversal of gene methylation can reactivate the expression of genes involved in resistance to chemotherapeutic drugs (152). For example, the use of decitabine and 5-FU in combination showed reactive expression of TFAP2E in GC by demethylating activity and enhancing the sensitivity of GC cells to 5-FU (153). Furthermore, a phase 1 trial of azacytidine combined to EOX (epirubicin, oxaliplatin and capecitabine) showed that this combination was well-tolerated with significant clinical and epigenetic responses $(67 \%)$ in patients with locally advanced gastric and esophageal adenocarcinoma (139). More prospective randomized studies will be needed to further investigate whether this combination is superior to EOX.

Zebularine. Compared to other DNMTi, zebularine (2(1H)-pyrimidinone riboside) is a novel DNMT inhibitor with high oral bioavailability, slight toxicity and high stability (154). Several preclinical studies have shown that zebularine can form a tight covalent complex with DNMTs and so reverse the hypermethylation of TSGs in cancer cell lines (155). Treatment with zebularine effectively inhibits GC cells proliferation by inducing cell death, causing apoptosis in a dose-dependent manner. Moreover, zebularine depletes expression of DNMT protein with re-expression of epigenetically silenced genes, such as p16 (142). These results indicated that zebularine is a promising drug for GC therapy, but further exploration is needed.

Inhibitors of HMTs and HDTs. In contrast to DNMTi, the agents targeting histone methylation is still at a primitive level (156). In 2005, the first study identified the effect of chaetocin, an inhibitor of HMT SUV39H1 (157). Subsequently, more and more inhibitors of various HMTs and HDTs, such as DOT1L (EPZ004777), EZH2 (EPZ-6438 and GSK126, EI1) and G9a (BIX-01294), were investigated as antitumor drugs (Fig. 1). Several inhibitors targeting DOT1L, EZH2 and LSD1, have entered phase 1/2 human clinical trials to assess the safety and maximum tolerated dose (Table IV). For example, EPZ-5676, the most advanced inhibitor for DOT1L that specifically catalyzes the mono-, di- and tri-methylation of H3K79, is currently in clinical trials for MLL-rearranged leukemia (NCT02141828 and NCT01684150). Major clinical studies that have been conducted so far are summarized in Table IV. Here, we summarize some common research targets in cancer, especially in GC.

EZH2 inhibitors. The first widely used EZH2 inhibitor, 3-deazaneplanocin A (DZNep), is a cyclopentanyl analog of 3-deazaneplanocine that potently interferes with S-adenosyl1-homocysteine hydrolase (SAH), which increases cellular SAH levels, repressing the activity of SAH-dependent HMT (158). It can inhibit PRC2 and remove H3K27me3 markers in various cancer types (159). Upon exposure to DZNep, EZH2 is depleted and ubiquitination of wild-type p53 protein is inhibited, resulting in p53 stabilization and activation of downstream p53 pathways involved in apoptosis, cell cycle arrest and senescence in GC cell lines (Table III) (144). However, DZNep has a short half-life and is both non-specific and toxic in animal models (160). GSK126 is an AdoMet-competitive chemical compound targeting Y641and A677-mutated EZH2 for the treatment of diffuse large B-cell lymphoma (DLBCL) (161). A recent study has shown that GSK126 suppressed tumor migration and angiogenesis via downregulation of VEGF-A expression in GC cell lines and rodent animals (162).

The subsequently developed small-molecule EZH2 inhibitor EPZ005687, has shown dose-dependent inhibition of H3K27me3 in EZH2-wild-type and Y641- and A677-mutant lymphoma cells as well as in cell lines of other cancer types, including breast and prostate cancer. In June 2013, a phase 1/2 clinical trial of EPZ-6438, with better oral bioavailability than EPZ005687 (163), was explored in patients with advanced solid tumors or B cell lymphomas (NCT01897571). EI1, a third SAM-competitive inhibitor, inhibits both wild-type and 
Table IV. Clinical trials based on the use of HMTi and HDTi in cancer.

\begin{tabular}{|c|c|c|c|c|c|c|}
\hline Inhibitors & Target & Intervention & Conditions & Phase & Status & Identifier \\
\hline \multirow[t]{2}{*}{ EPZ-5676 } & \multirow[t]{2}{*}{ DOT1L } & Drug: EPZ-5676 & AML, ALL, AL & 1 & Completed & NCT02141828 \\
\hline & & Drug: EPZ-5676 & AML, ALL, MDS, MPD & 1 & Completed & NCT01684150 \\
\hline \multirow{12}{*}{$\begin{array}{l}\text { EPZ-6438/ } \\
\text { Tazemetostat }\end{array}$} & \multirow[t]{2}{*}{$\mathrm{EZH} 2$} & \multirow[t]{2}{*}{ Drug: EPZ-6438/E7438 } & B-cell lymphomas (phase 1), & \multirow[t]{2}{*}{$1 / 2$} & \multirow[t]{2}{*}{ Recruiting } & \multirow[t]{2}{*}{ NCT01897571 } \\
\hline & & & $\begin{array}{l}\text { advanced solid tumors (phase 1), } \\
\text { DLBCL (phase 2), FL (phase 2), } \\
\text { transformed FL, PMBL }\end{array}$ & & & \\
\hline & \multirow[t]{6}{*}{$\mathrm{EZH} 2$} & Drug: Tazemetostat & DLBCL & \multirow[t]{6}{*}{$1 / 2$} & \multirow{6}{*}{$\begin{array}{l}\text { Not yet } \\
\text { recruiting }\end{array}$} & \multirow[t]{6}{*}{ NCT02889523 } \\
\hline & & Drug: Rituximab & & & & \\
\hline & & Drug: Cyclophosphamide & & & & \\
\hline & & Drug: Vincristine & & & & \\
\hline & & Drug: Doxorubicin & & & & \\
\hline & & Drug: Prednisolone & & & & \\
\hline & $\mathrm{EZH} 2$ & Drug: Tazemetostat & $\begin{array}{l}\text { MRT, RTK, ATRT, selected } \\
\text { tumors with rhabdoid features } \\
\text { SS, INI1-negative tumors, } \\
\text { nalignant rhabdoid tumor of } \\
\text { ovary, renal MC, epithelioid } \\
\text { sarcoma }\end{array}$ & 2 & Recruiting & NCT02601950 \\
\hline & $\mathrm{EZH} 2$ & Drug: Tazemetostat & $\begin{array}{l}\text { DLBCL, FL, MRT, RTK, ATRT, } \\
\text { SS, ES, mesothelioma, advanced } \\
\text { solid tumors }\end{array}$ & 2 & Recruiting & NCT02875548 \\
\hline & $\mathrm{EZH2}$ & Drug: Tazemetostat & $\begin{array}{l}\text { Mesothelioma with BAP1 loss } \\
\text { of function }\end{array}$ & 2 & Recruiting & NCT02860286 \\
\hline & $\mathrm{EZH} 2$ & Drug: Tazemetostat & $\begin{array}{l}\text { Rhabdoid tumors, INI1- } \\
\text { negative tumors, } \mathrm{SS}, \\
\text { malignant rhabdoid tumor of } \\
\text { ovary }\end{array}$ & 1 & Recruiting & NCT02601937 \\
\hline GSK2816126 & $\mathrm{EZH} 2$ & Drug: GSK2816126 & $\begin{array}{l}\text { Relapsed/refractory DLBCL, } \\
\text { transformed FL, other NHL, } \\
\text { solid tumors, multiple myeloma }\end{array}$ & 1 & Recruiting & NCT02082977 \\
\hline CPI-1205 & $\mathrm{EZH} 2$ & Drug: CPI-1205 & B-cell lymphoma & 1 & Recruiting & NCT02395601 \\
\hline DS-3201b & $\mathrm{EZH} 1 / 2$ & Drug: DS-3201b & DLBCL, FL, ATLL & 1 & Recruiting & NCT02732275 \\
\hline \multirow[t]{7}{*}{ TCP } & \multirow[t]{3}{*}{ LSD1 } & Drug: TCP & \multirow[t]{3}{*}{ AML, MDS } & \multirow[t]{3}{*}{$1 / 2$} & \multirow[t]{3}{*}{ Recruiting } & \multirow[t]{3}{*}{ NCT02717884 } \\
\hline & & Drug: ATRC & & & & \\
\hline & & Drug: Cytarabine & & & & \\
\hline & \multirow[t]{2}{*}{ LSD1 } & Drug: TCP & \multirow[t]{2}{*}{ AML, MDS } & \multirow[t]{2}{*}{1} & \multirow[t]{2}{*}{ Recruiting } & \multirow[t]{2}{*}{ NCT02273102 } \\
\hline & & Drug: Tretinoin & & & & \\
\hline & \multirow[t]{2}{*}{ LSD1 } & Drug: TCP & \multirow[t]{2}{*}{ AML } & $1 / 2$ & Recruiting & NCT02261779 \\
\hline & & Drug: Tretinoin & & & & \\
\hline GSK2879552 & LSD1 & Drug: GSK2879552 & MDS & 2 & Not yet & NCT02929498 \\
\hline & & Drug: Azacitidine & & & recruiting & \\
\hline & LSD1 & Drug: GSK2879552 & SCLC & 1 & Recruiting & NCT02034123 \\
\hline & LSD1 & Drug: GSK2879552 & AML & 1 & Recruiting & NCT02177812 \\
\hline INCB059872 & LSD1 & Drug: INCB059872 & Advanced cancer & $1 / 2$ & Recruiting & NCT02712905 \\
\hline IMG-7289 & LSD1 & Drug: IMG-7289 & AML, MDS & 1 & Recruiting & NCT02842827 \\
\hline & & Drug: ATRA & & & & \\
\hline
\end{tabular}


Table IV. Continued.

\begin{tabular}{llccccc}
\hline Inhibitors & Target & Intervention & Conditions & Phase & Status & Identifier \\
\hline ORY-1001 & LSD1 & Drug: ORY-1001 & AL & 1 & Recruiting & 2013-002447-29
\end{tabular}

Data from https://clinicaltrials.gov and https://clinicaltrialsregister.eu. TCP, tranylcypromine; AML, acute myelogenous leukemia; ALL, acute lymphocytic leukemia; MDS, myelodysplastic syndrome; MPD, myeloproliferative disorders; DLBCL, diffuse large B-cell Lymphoma; SS, synovial sarcoma; FL, follicular lymphoma; PMBL, primary mediastinal large B-cell lymphoma; MRT, malignant rhabdoid tumors, RTK, rhabdoid tumors of the kidney; ATRT, atypical teratoid rhabdoid tumors; ES, epitheliod sarcoma; MC, medullary carcinoma; NHL, non-Hodgkin's lymphomas; SCLC, small cell lung carcinoma; ATLL, adult T-cell leukemia lymphoma; AL, acute leukemia; ATRA, all-trans retinoic acid.

mutant EZH2 and alters H3K27me2 and H3K27me3 levels in EZH2-mutant DLBCL cells in a SMARCB1-mutant rhabdoid tumor cell line (164). EZH2 silencing promoted growth arrest by low concentrations of doxorubicin in p53 mutant gastric cancer cells (165). The combination of EZH2 inhibitors and doxorubicin may be a potential novel approach to GC treatment.

LSD1 inhibitors. LSD1, which demethylates both H3K4 and H3K9 residues, is overexpressed in GCs (Table II) (109). It may be a promising target for GC therapy. Tranylcypromine (TCP), an inhibitor of FAD-dependent monoamine oxidases (MAO), was the first small molecule used to target LSD1 because of the close homology between LSD1 and the MAO $(166,167)$. Recent reports have highlighted the potential efficacy of TCP alone or combination with all-trans-retinoic acid (ATRA) in acute myeloid leukemia (AML) (Table IV). After that, TCP derivatives such as GSK2879552 and ORY-1001 were initiated for patients with relapsed/refractory small-cell lung cancer and AML in clinical trials (Table IV). Although no reports have shown whether these inhibitors can be used in GC, LSD1 inhibitors are worthy of further research into GC.

\section{Conclusion}

Over the past decade, epigenetic regulation has been proven to play a pivotal role in cancer pathogenesis. As an important subgroup, DNA and histone methylation have been reported to control numerous cancer suppressor genes and protooncogenes. In GC, hyper- and hypo-methylation events are critical to tumor onset. Of note, histone methylation plays an important role in chromatin regulators and GC tumorigenesis. The many HMTs and HDMs that have been identified can mediate the addition and removal of methyl groups from different lysine residues on histones and display distinct functions. These methylation enzymes have attracted considerable attention as potential targets for GC treatment. Recently, numerous trials have been made to develop and identify molecules targeting these enzymes. In many studies, the use of methylation regulators in combination with already existing chemotherapy results in better outcomes in many studies. However, these regulators still have risks of off-target toxicity and many chromatin-modifying enzymes have more diverse functions. Thus, understanding the underlying epigenetic molecular mechanisms, discovering new targets and agents will be essential to successful targeted epigenetic therapy in the future.

\section{Acknowledgements}

We apologize to all groups whose important contributions to methylation regulation were not mentioned in this review due to space limitation. The present review was partly supported by the Innovation Fund of Shanghai Committee of Science and Technology (no. 14ZR1406600).

\section{References}

1. Brenner H, Rothenbacher D and Arndt V: Epidemiology of stomach cancer. Methods Mol Biol 472: 467-477, 2009.

2. Leung WK, Wu MS, Kakugawa Y, Kim JJ, Yeoh KG, Goh KL, Wu KC, Wu DC, Sollano J, Kachintorn U, et al; Asia Pacific Working Group on Gastric Cancer: Screening for gastric cancer in Asia: Current evidence and practice. Lancet Oncol 9: 279-287, 2008.

3. Nakamura J, Tanaka T, Kitajima Y, Noshiro H and Miyazaki K: Methylation-mediated gene silencing as biomarkers of gastric cancer: A review. World J Gastroenterol 20: 11991-12006, 2014.

4. Sharma S, Kelly TK and Jones PA: Epigenetics in cancer. Carcinogenesis 31: 27-36, 2010.

5. Suzuki MM and Bird A: DNA methylation landscapes: Provocative insights from epigenomics. Nat Rev Genet 9: 465-476, 2008.

6. Eden A, Gaudet F, Waghmare A and Jaenisch R: Chromosomal instability and tumors promoted by DNA hypomethylation. Science 300: 455, 2003.

7. Karpf AR and Matsui S: Genetic disruption of cytosine DNA methyltransferase enzymes induces chromosomal instability in human cancer cells. Cancer Res 65: 8635-8639, 2005.

8. Schulz WA: L1 retrotransposons in human cancers. J Biomed Biotechnol 2006: 83672, 2006.

9. Esteller M: Epigenetics in cancer. N Engl J Med 358: 1148-1159, 2008.

10. Ehrlich M: DNA methylation in cancer: Too much, but also too little. Oncogene 21: 5400-5413, 2002.

11. Omenn GS: Strategies for plasma proteomic profiling of cancers. Proteomics 6: 5662-5673, 2006.

12. Momparler RL and Bovenzi V: DNA methylation and cancer. J Cell Physiol 183: 145-154, 2000.

13. Robertson DS: Cellular configuration of DNA and cell division. Med Hypotheses 57: 344-353, 2001.

14. Fuks F, Hurd PJ, Deplus R and Kouzarides T: The DNA methyltransferases associate with HP1 and the SUV39H1 histone methyltransferase. Nucleic Acids Res 31: 2305-2312, 2003.

15. Kouzarides T: Chromatin modifications and their function. Cell 128: 693-705, 2007.

16. Tan M, Luo H, Lee S, Jin F, Yang JS, Montellier E, Buchou T, Cheng Z, Rousseaux S, Rajagopal N, et al: Identification of 67 histone marks and histone lysine crotonylation as a new type of histone modification. Cell 146: 1016-1028, 2011.

17. Kouzarides T: SnapShot: Histone-modifying enzymes. Cell 131: 822-822.e1, 2007.

18. Gigek CO, Chen ES, Calcagno DQ, Wisnieski F, Burbano RR and Smith MA: Epigenetic mechanisms in gastric cancer. Epigenomics 4: 279-294, 2012. 
19. Ushijima T and Sasako M: Focus on gastric cancer. Cancer Cell 5: 121-125, 2004.

20. Park JH, Park J, Choi JK, Lyu J, Bae MG, Lee YG, Bae JB, Park DY, Yang HK, Kim TY, et al: Identification of DNA methylation changes associated with human gastric cancer. BMC Med Genomics 4: 82, 2011.

21. Yoshida T, Yamashita S, Takamura-Enya T, Niwa T, Ando T, Enomoto S, Maekita T, Nakazawa K, Tatematsu M, Ichinose M, et al: Alu and Sata hypomethylation in Helicobacter pyloriinfected gastric mucosae. Int J Cancer 128: 33-39, 2011.

22. Jang BG and Kim WH: Molecular pathology of gastric carcinoma. Pathobiology 78: 302-310, 2011.

23. Leodolter A, Alonso S, González B, Ebert MP, Vieth M, Röcken C, Wex T, Peitz U, Malfertheiner P and Perucho M: Somatic DNA Hypomethylation in H.pylori-associated high-risk gastritis and gastric cancer: Enhanced somatic hypomethylation associates with advanced stage cancer. Clin Transl Gastroenterol 6: e85, 2015.

24. Kosumi K, Baba Y, Ishimoto T, Harada K, Miyake K, Izumi D, Tokunaga R, Murata A, Eto K, Sugihara H, et al: Relationship between LINE-1 hypomethylation and Helicobacter pylori infection in gastric mucosae. Med Oncol 32: 117, 2015.

25. Shigaki H, Baba Y, Watanabe M, Murata A, Iwagami S, Miyake K, Ishimoto T, Iwatsuki M and Baba H: LINE-1 hypomethylation in gastric cancer, detected by bisulfite pyrosequencing, is associated with poor prognosis. Gastric Cancer 16: 480-487, 2013.

26. Xiang S, Liu Z, Zhang B, Zhou J, Zhu BD, Ji J and Deng D: Methylation status of individual CpG sites within Alu elements in the human genome and Alu hypomethylation in gastric carcinomas. BMC Cancer 10: 44, 2010.

27. Yuasa Y, Nagasaki H, Oze I, Akiyama Y, Yoshida S, Shitara K, Ito S, Hosono S, Watanabe $\mathrm{M}$, Ito $\mathrm{H}$, et al: Insulin-like growth factor 2 hypomethylation of blood leukocyte DNA is associated with gastric cancer risk. Int J Cancer 131: 2596-2603, 2012.

28. Hansen KD, Timp W, Bravo HC, Sabunciyan S, Langmead B, McDonald OG, Wen B, Wu H, Liu Y, Diep D, et al: Increased methylation variation in epigenetic domains across cancer types. Nat Genet 43: 768-775, 2011.

29. Song SH, Jong HS, Choi HH, Kang SH, Ryu MH, Kim NK, Kim WH and Bang YJ: Methylation of specific CpG sites in the promoter region could significantly down-regulate $16^{\mathrm{INK} 4 \mathrm{a}}$ expression in gastric adenocarcinoma. Int J Cancer 87: 236-240, 2000.

30. Shu XS, Geng H, Li L, Ying J, Ma C, Wang Y, Poon FF, Wang X, Ying Y, Yeo W, et al: The epigenetic modifier PRDM5 functions as a tumor suppressor through modulating $\mathrm{WNT} / \beta$-catenin signaling and is frequently silenced in multiple tumors. PLoS One 6: e27346, 2011.

31. Joo JK, Kim SH, Kim HG, Kim DY, Ryu SY, Lee KH and Lee JH: $\mathrm{CpG}$ methylation of transcription factor 4 in gastric carcinoma. Ann Surg Oncol 17: 3344-3353, 2010.

32. Jung HY, Jung KC, Shim YH, Ro JY and Kang GH: Methylation of the hMLH1 promoter in multiple gastric carcinomas with microsatellite instability. Pathol Int 51: 445-451, 2001.

33. Yousuf A, Bhat MY, Pandith AA, Afroze D, Khan NP, Alam K, Shah P, Shah MA and Mudassar S: MGMT gene silencing by promoter hypermethylation in gastric cancer in a high incidence area. Cell Oncol (Dordr) 37: 245-252, 2014

34. Cheng YY, Yu J, Wong YP, Man EP, To KF, Jin VX, Li J, Tao Q, Sung JJ, Chan FK, et al: Frequent epigenetic inactivation of secreted frizzled-related protein 2 (SFRP2) by promoter methylation in human gastric cancer. Br J Cancer 97: 895-901, 2007.

35. Nojima M, Suzuki H, Toyota M, Watanabe Y, Maruyama R, Sasaki S, Sasaki Y, Mita H, Nishikawa N, Yamaguchi K, et al: Frequent epigenetic inactivation of SFRP genes and constitutive activation of Wnt signaling in gastric cancer. Oncogene 26: 4699-4713, 2007.

36. Ebert MP, Yu J, Hoffmann J, Rocco A, Röcken C, Kahmann S, Müller O, Korc M, Sung JJ and Malfertheiner P: Loss of betacatenin expression in metastatic gastric cancer. J Clin Oncol 21: 1708-1714, 2003.

37. Oshimo Y, Kuraoka K, Nakayama H, Kitadai Y, Yoshida K, Chayama $\mathrm{K}$ and Yasui W: Epigenetic inactivation of SOCS-1 by $\mathrm{CpG}$ island hypermethylation in human gastric carcinoma. Int J Cancer 112: 1003-1009, 2004.

38. Kim TY, Lee HJ, Hwang KS, Lee M, Kim JW, Bang YJ and Kang GH: Methylation of RUNX3 in various types of human cancers and premalignant stages of gastric carcinoma. Lab Invest 84: 479-484, 2004.
39. Byun DS, Lee MG, Chae KS, Ryu BG and Chi SG: Frequent epigenetic inactivation of RASSFIA by aberrant promoter hypermethylation in human gastric adenocarcinoma. Cancer Res 61: 7034-7038, 2001

40. Hayashi K, Yokozaki H, Goodison S, Oue N, Suzuki T, Lotan R, Yasui $\mathrm{W}$ and Tahara E: Inactivation of retinoic acid receptor beta by promoter $\mathrm{CpG}$ hypermethylation in gastric cancer. Differentiation 68: 13-21, 2001

41. Yu J, Tao Q, Cheng YY, Lee KY, Ng SS, Cheung KF, Tian L, Rha SY, Neumann U, Röcken C, et al: Promoter methylation of the Wnt/beta-catenin signaling antagonist Dkk-3 is associated with poor survival in gastric cancer. Cancer 115: 49-60, 2009.

42. Nishigaki M, Aoyagi K, Danjoh I, Fukaya M, Yanagihara K, Sakamoto H, Yoshida T and Sasaki H: Discovery of aberrant expression of $R-R A S$ by cancer-linked DNA hypomethylation in gastric cancer using microarrays. Cancer Res 65: 2115-2124, 2005.

43. Mulero-Navarro S and Esteller M: Epigenetic biomarkers for human cancer: The time is now. Crit Rev Oncol Hematol 68: $1-11,2008$.

44. Oue N, Matsumura S, Nakayama H, Kitadai Y, Taniyama K, Matsusaki K and Yasui W: Reduced expression of the TSP1 gene and its association with promoter hypermethylation in gastric carcinoma. Oncology 64: 423-429, 2003.

45. Ganesan K, Ivanova T, Wu Y, Rajasegaran V, Wu J, Lee MH, Yu K, Rha SY, Chung HC, Ylstra B, et al: Inhibition of gastric cancer invasion and metastasis by PLA2G2A, a novel betacatenin/TCF target gene. Cancer Res 68: 4277-4286, 2008.

46. Chan AW, Chan MW, Lee TL, Ng EK, Leung WK, Lau JY, Tong JH, Chan FK and To KF: Promoter hypermethylation of Death-associated protein-kinase gene associated with advance stage gastric cancer. Oncol Rep 13: 937-941, 2005.

47. Yu J, Cheng YY, Tao Q, Cheung KF, Lam CN, Geng H, Tian LW, Wong YP, Tong JH, Ying JM, et al: Methylation of protocadherin 10 , a novel tumor suppressor, is associated with poor prognosis in patients with gastric cancer. Gastroenterology 136: 640-51.e1, 2009.

48. Hu X, Sui X, Li L, Huang X, Rong R, Su X, Shi Q, Mo L, Shu X, Kuang Y, et al: Protocadherin 17 acts as a tumour suppressor inducing tumour cell apoptosis and autophagy, and is frequently methylated in gastric and colorectal cancers. J Pathol 229: 62-73, 2013.

49. Haruki S, Imoto I, Kozaki K, Matsui T, Kawachi H, Komatsu S, Muramatsu T, Shimada Y, Kawano T and Inazawa J: Frequent silencing of protocadherin 17, a candidate tumour suppressor for esophageal squamous cell carcinoma. Carcinogenesis 31 : 1027-1036, 2010

50. Hiraki M, Kitajima Y, Koga Y, Tanaka T, Nakamura J, Hashiguchi K, Noshiro $\mathrm{H}$ and Miyazaki K: Aberrant gene methylation is a biomarker for the detection of cancer cells in peritoneal wash samples from advanced gastric cancer patients. Ann Surg Oncol 18: 3013-3019, 2011.

51. Xu L, Li X, Chu ES, Zhao G, Go MY, Tao Q, Jin H, Zeng Z, Sung JJ and Yu J: Epigenetic inactivation of BCL6B, a novel functional tumour suppressor for gastric cancer, is associated with poor survival. Gut 61: 977-985, 2012.

52. Xie B, Zhou J, Shu G, Liu DC, Zhou J, Chen J and Yuan L: Restoration of klotho gene expression induces apoptosis and autophagy in gastric cancer cells: Tumor suppressive role of klotho in gastric cancer. Cancer Cell Int 13: 18, 2013.

53. Kwon OH, Park JL, Baek SJ, Noh SM, Song KS, Kim SY and Kim YS: Aberrant upregulation of ASCL2 by promoter demethylation promotes the growth and resistance to 5-fluorouracil of gastric cancer cells. Cancer Sci 104: 391-397, 2013.

54. Gigek CO, Lisboa LC, Leal MF, Silva PN, Lima EM, Khayat AS, Assumpção PP, Burbano RR and Smith MA: SMARCA5 methylation and expression in gastric cancer. Cancer Invest 29: 162-166, 2011.

55. Xiong HL, Liu XQ, Sun AH, He Y, Li J and Xia Y: Aberrant DNA methylation of P16, MGMT, hMLH1 and hMSH2 genes in combination with the MTHFR C677T genetic polymorphism in gastric cancer. Asian Pac J Cancer Prev 14: 3139-3142, 2013.

56. Hamai Y, Oue N, Mitani Y, Nakayama H, Ito R, Matsusaki K, Yoshida K, Toge T and Yasui W: DNA hypermethylation and histone hypoacetylation of the HLTF gene are associated with reduced expression in gastric carcinoma. Cancer Sci 94: 692-698, 2003.

57. Wang L, Xie L, Wang J, Shen J and Liu B: Correlation between the methylation of SULF2 and WRN promoter and the irinotecan chemosensitivity in gastric cancer. BMC Gastroenterol 13: 173, 2013. 
58. Ivanova $\mathrm{T}$, Zouridis $\mathrm{H}, \mathrm{Wu} \mathrm{Y}$, Cheng LL, Tan IB Gopalakrishnan V, Ooi CH, Lee J, Qin L, Wu J, et al: Integrated epigenomics identifies BMP4 as a modulator of cisplatin sensitivity in gastric cancer. Gut 62: 22-33, 2013.

59. Zouridis H, Deng N, Ivanova T, Zhu Y, Wong B, Huang D, Wu YH, Wu Y, Tan IB, Liem N, et al: Methylation subtypes and large-scale epigenetic alterations in gastric cancer. Sci Transl Med 4: 156ra140, 2012.

60. Selaru FM, David S, Meltzer SJ and Hamilton JP: Epigenetic events in gastrointestinal cancer. Am J Gastroenterol 104: 1910-1912, 2009

61. Yamamoto E, Suzuki H, Takamaru H, Yamamoto H, Toyota M and Shinomura Y: Role of DNA methylation in the development of diffuse-type gastric cancer. Digestion 83: 241-249, 2011.

62. Cavallaro U and Christofori G: Multitasking in tumor progression: Signaling functions of cell adhesion molecules. Ann NY Acad Sci 1014: 58-66, 2004.

63. Zong $\mathrm{L}$ and Seto $\mathrm{Y}$ : $\mathrm{CpG}$ island methylator phenotype, Helicobacter pylori, Epstein-Barr virus, and microsatellite instability and prognosis in gastric cancer: A systematic review and meta-analysis. PLoS One 9: e86097, 2014.

64. Ding WJ, Fang JY, Chen XY and Peng YS: The expression and clinical significance of DNA methyltransferase proteins in human gastric cancer. Dig Dis Sci 53: 2083-2089, 2008

65. Yang J, Wei X, Wu Q, Xu Z, Gu D, Jin Y, Shen Y, Huang H, Fan $\mathrm{H}$ and Chen J: Clinical significance of the expression of DNA methyltransferase proteins in gastric cancer. Mol Med Rep 4: 1139-1143, 2011

66. Cao XY, Ma HX, Shang YH, Jin MS, Kong F, Jia ZF, Cao DH, Wang YP, Suo J and Jiang J: DNA methyltransferase3a expression is an independent poor prognostic indicator in gastric cancer. World J Gastroenterol 20: 8201-8208, 2014.

67. Cui H, Zhao C, Gong P, Wang L, Wu H, Zhang K, Zhou R, Wang L, Zhang T, Zhong S, et al: DNA methyltransferase 3A promotes cell proliferation by silencing CDK inhibitor p18 ${ }^{\mathrm{INK} 4 \mathrm{C}}$ in gastric carcinogenesis. Sci Rep 5: 13781, 2015.

68. Ley TJ, Ding L, Walter MJ, McLellan MD, Lamprecht T, Larson DE, Kandoth C, Payton JE, Baty J, Welch J, et al: DNMT3A mutations in acute myeloid leukemia. N Engl J Med 363: 2424-2433, 2010.

69. Zang ZJ, Cutcutache I, Poon SL, Zhang SL, McPherson JR, Tao J, Rajasegaran V, Heng HL, Deng N, Gan A, et al: Exome sequencing of gastric adenocarcinoma identifies recurrent somatic mutations in cell adhesion and chromatin remodeling genes. Nat Genet 44: 570-574, 2012.

70. Kim MS, Kim YR, Yoo NJ and Lee SH: Mutational analysis of DNMT3A gene in acute leukemias and common solid cancers. APMIS 121: 85-94, 2013

71. Kanai Y, Ushijima S, Kondo Y, Nakanishi Y and Hirohashi S: DNA methyltransferase expression and DNA methylation of CPG islands and peri-centromeric satellite regions in human colorectal and stomach cancers. Int J Cancer 91: 205-212, 2001.

72. Hu J, Fan H, Liu D, Zhang S, Zhang F and Xu H: DNMT3B promoter polymorphism and risk of gastric cancer. Dig Dis Sci 55: 1011-1016, 2010.

73. Li H, Li W, Liu S, Zong S, Wang W, Ren J, Li Q, Hou F and Shi Q DNMT1, DNMT3A and DNMT3B polymorphisms associated with gastric cancer risk: A systematic review and meta-analysis. EBioMedicine 13: 125-131, 2016.

74. Tang H, Deng M, Tang Y, Xie X, Guo J, Kong Y, Ye F, Su Q and Xie X: miR-200b and miR-200c as prognostic factors and mediators of gastric cancer cell progression. Clin Cancer Res 19: $5602-5612,2013$

75. Zhang BG, Hu L, Zang MD, Wang HX, Zhao W, Li JF, Su LP, Shao Z, Zhao X, Zhu ZG, et al: Helicobacter pylori CagA induces tumor suppressor gene hypermethylation by upregulating DNMT1 via AKT-NF- $\kappa$ B pathway in gastric cancer development. Oncotarget 7: 9788-9800, 2016.

76. Wallasch C, Crabtree JE, Bevec D, Robinson PA, Wagner H and Ullrich A: Helicobacter pylori-stimulated EGF receptor transactivation requires metalloprotease cleavage of HB-EGF. Biochem Biophys Res Commun 295: 695-701, 2002.

77. Hino R, Uozaki H, Murakami N, Ushiku T, Shinozaki A, Ishikawa S, Morikawa T, Nakaya T, Sakatani T, Takada K, et al: Activation of DNA methyltransferase 1 by EBV latent membrane protein 2A leads to promoter hypermethylation of PTEN gene in gastric carcinoma. Cancer Res 69: 2766-2774, 2009

78. Liang Q, Yao X, Tang S, Zhang J, Yau TO, Li X, Tang CM, Kang W, Lung RW, Li JW, et al: Integrative identification of Epstein-Barr virus-associated mutations and epigenetic alterations in gastric cancer. Gastroenterology 147: 1350-62.e4, 2014.
79. Liu J, Zhu X, Xu X and Dai D: DNA promoter and histone H3 methylation downregulate NGX6 in gastric cancer cells. Med Oncol 31: 817, 2014.

80. Park YS, Jin MY, Kim YJ, Yook JH, Kim BS and Jang SJ: The global histone modification pattern correlates with cancer recurrence and overall survival in gastric adenocarcinoma. Ann Surg Oncol 15: 1968-1976, 2008

81. Lee H, Yoon SO, Jeong WY, Kim HK, Kim A and Kim BH: Immunohistochemical analysis of polycomb group protein expression in advanced gastric cancer. Hum Pathol 43: 1704-1710, 2012.

82. He LJ, Cai MY, Xu GL, Li JJ, Weng ZJ, Xu DZ, Luo GY, Zhu SL and Xie D: Prognostic significance of overexpression of EZH2 and $\mathrm{H} 3 \mathrm{k} 27 \mathrm{me} 3$ proteins in gastric cancer. Asian Pac J Cancer Prev 13: 3173-3178, 2012.

83. Kwon OH, Park JL, Kim M, Kim JH, Lee HC, Kim HJ, Noh SM, Song KS, Yoo HS, Paik SG, et al: Aberrant up-regulation of $L A M B 3$ and $L A M C 2$ by promoter demethylation in gastric cancer. Biochem Biophys Res Commun 406: 539-545, 2011.

84. Komatsu S, Ichikawa D, Hirajima S, Nagata H, Nishimura Y, Kawaguchi T, Miyamae M, Okajima W, Ohashi T, Konishi H, et al: Overexpression of SMYD2 contributes to malignant outcome in gastric cancer. Br J Cancer 112: 357-364, 2015.

85. Liu Y, Deng J, Luo X, Pan Y, Zhang L, Zhang R and Liang H: Overexpression of SMYD3 was associated with increased STAT3 activation in gastric cancer. Med Oncol 32: 404, 2015.

86. Liu H, Liu Y, Kong F, Xin W, Li X, Liang H and Jia Y: Elevated levels of SET and MYND domain-containing protein 3 are correlated with overexpression of transforming growth factor- $\beta 1$ in gastric cancer. J Am Coll Surg 221: 579-590, 2015

87. Liu Y, Liu H, Luo X, Deng J, Pan Y and Liang H: Overexpression of SMYD3 and matrix metalloproteinase-9 are associated with poor prognosis of patients with gastric cancer. Tumour Biol 36: 4377-4386, 2015.

88. Liu Y, Luo X, Deng J, Pan Y, Zhang L and Liang H: SMYD3 overexpression was a risk factor in the biological behavior and prognosis of gastric carcinoma. Tumour Biol 36: 2685-2694, 2015.

89. Cai L, Ma X, Huang Y, Zou Y and Chen X: Aberrant histone methylation and the effect of Suv39H1 siRNA on gastric carcinoma. Oncol Rep 31: 2593-2600, 2014.

90. Fujii S, Ito K, Ito Y and Ochiai A: Enhancer of zeste homologue 2 (EZH2) down-regulates RUNX3 by increasing histone H3 methylation. J Biol Chem 283: 17324-17332, 2008.

91. Qi Y, Zhang X, Kang Y, Wu J, Chen J, Li H, Guo Y, Liu B, Shao Z and Zhao X: Genome-wide transcriptional profiling analysis reveals annexin A6 as a novel EZH2 target gene involving gastric cellular proliferation. Mol Biosyst 11: 1980-1986, 2015.

92. Fujii S and Ochiai A: Enhancer of zeste homolog 2 downregulates E-cadherin by mediating histone $\mathrm{H} 3$ methylation in gastric cancer cells. Cancer Sci 99: 738-746, 2008

93. Tong Y, Li Y, Gu H, Wang C, Liu F, Shao Y, Li J, Cao L and Li F: Microchidia protein 2, MORC2, downregulates the cytoskeleton adapter protein, ArgBP2, via histone methylation in gastric cancer cells. Biochem Biophys Res Commun 467: 821-827, 2015.

94. Bai J, Chen J, Ma M, Cai M, Xu F, Wang G, Tao K and Shuai X: Inhibiting enhancer of zeste homolog 2 promotes cellular senescence in gastric cancer cells SGC-7901 by activation of p21 and p16. DNA Cell Biol 33: 337-344, 2014.

95. Jie B, Weilong C, Ming C, Fei X, Xinghua L, Junhua C, Guobin W, Kaixiong $\mathrm{T}$ and Xiaoming S: Enhancer of zeste homolog 2 depletion induces cellular senescence via histone demethylation along the INK4/ARF locus. Int J Biochem Cell Biol 65: 104-112, 2015 .

96. Lu H, Sun J, Wang F, Feng L, Ma Y, Shen Q, Jiang Z, Sun X, Wang $\mathrm{X}$ and Jin $\mathrm{H}$ : Enhancer of zeste homolog 2 activates wnt signaling through downregulating CXXC finger protein 4. Cell Death Dis 4: e776, 2013.

97. Lu H, Jin W, Sun J, Feng L, Lan H, Shen Q, Ma Y, Li J, Yue Y, Jin $\mathrm{H}$, et al: New tumor suppressor CXXC finger protein 4 inactivates mitogen activated protein kinase signaling. FEBS Lett 588: 3322-3326, 2014

98. Akiyama Y, Koda Y, Byeon SJ, Shimada S, Nishikawaji T, Sakamoto A, Chen Y, Kojima K, Kawano T, Eishi Y, et al: Reduced expression of SET7/9, a histone mono-methyltransferase, is associated with gastric cancer progression. Oncotarget 7: 3966-3983, 2016.

99. Zeng J, Ge Z, Wang L, Li Q, Wang N, Björkholm M, Jia J and $\mathrm{Xu}$ D: The histone demethylase RBP2 is overexpressed in gastric cancer and its inhibition triggers senescence of cancer cells. Gastroenterology 138: 981-992, 2010. 
100. Wang Z, Tang F, Qi G, Yuan S, Zhang G, Tang B and He S: $\mathrm{KDM} 5 \mathrm{~B}$ is overexpressed in gastric cancer and is required for gastric cancer cell proliferation and metastasis. Am J Cancer Res 5: 87-100, 2014.

101. Li Y, Tian X, Sui CG, Jiang YH, Liu YP and Meng FD: Interference of lysine-specific demethylase 1 inhibits cellular invasion and proliferation in vivo in gastric cancer MKN-28 cells. Biomed Pharmacother 82: 498-508, 2016.

102. Yang H, Liu Z, Yuan C, Zhao Y, Wang L, Hu J, Xie D, Wang L and Chen D: Elevated JMJD1A is a novel predictor for prognosis and a potential therapeutic target for gastric cancer. Int $\mathbf{J}$ Clin Exp Pathol 8: 11092-11099, 2015.

103. Hu CE, Liu YC, Zhang HD and Huang GJ: JMJD2A predicts prognosis and regulates cell growth in human gastric cancer. Biochem Biophys Res Commun 449: 1-7, 2014.

104. Li W, Zhao L, Zang W, Liu Z, Chen L, Liu T, Xu D and Jia J: Histone demethylase JMJD2B is required for tumor cell proliferation and survival and is overexpressed in gastric cancer. Biochem Biophys Res Commun 416: 372-378, 2011

105. Zhao L, Li W, Zang W, Liu Z, Xu X, Yu H, Yang Q and Jia J: JMJD2B promotes epithelial-mesenchymal transition by cooperating with $\beta$-catenin and enhances gastric cancer metastasis. Clin Cancer Res 19: 6419-6429, 2013.

106. Taverna SD, Li H, Ruthenburg AJ, Allis CD and Patel DJ: How chromatin-binding modules interpret histone modifications: Lessons from professional pocket pickers. Nat Struct Mol Biol 14: $1025-1040,2007$

107. He C, Xu J, Zhang J, Xie D, Ye H, Xiao Z, Cai M, Xu K, Zeng Y, $\mathrm{Li} \mathrm{H}$, et al: High expression of trimethylated histone $\mathrm{H} 3$ lysine 4 is associated with poor prognosis in hepatocellular carcinoma. Hum Pathol 43: 1425-1435, 2012.

108. Zee BM, Levin RS, Xu B, LeRoy G, Wingreen NS and Garcia BA In vivo residue-specific histone methylation dynamics. J Biol Chem 285: 3341-3350, 2010

109. Tsukada Y, Fang J, Erdjument-Bromage H, Warren ME, Borchers $\mathrm{CH}$, Tempst $\mathrm{P}$ and Zhang Y: Histone demethylation by a family of JmjC domain-containing proteins. Nature 439 : 811-816, 2006

110. Huang $\mathrm{J}$ and Berger SL: The emerging field of dynamic lysine methylation of non-histone proteins. Curr Opin Genet Dev 18: 152-158, 2008.

111. Tan JZ, Yan Y, Wang XX, Jiang Y and Xu HE: EZH2: Biology, disease, and structure-based drug discovery. Acta Pharmacol Sin 35: 161-174, 2014

112. Ning X, Shi Z, Liu X, Zhang A, Han L, Jiang K, Kang C and Zhang Q: DNMT1 and EZH2 mediated methylation silences the microRNA-200b/a/429 gene and promotes tumor progression. Cancer Lett 359: 198-205, 2015.

113. Viré E, Brenner C, Deplus R, Blanchon L, Fraga M, Didelot C, Morey L, Van Eynde A, Bernard D, Vanderwinden JM, et al: The Polycomb group protein EZH2 directly controls DNA methylation. Nature 439: 871-874, 2006

114. Ma J, Wang JD, Zhang WJ, Zou B, Chen WJ, Lam CS, Chen MH Pang R, Tan VP, Hung IF, et al: Promoter hypermethylation and histone hypoacetylation contribute to pancreatic-duodenal homeobox 1 silencing in gastric cancer. Carcinogenesis 31 1552-1560, 2010.

115. Meng CF, Zhu XJ, Peng G and Dai DQ: Promoter histone H3 lysine 9 di-methylation is associated with DNA methylation and aberrant expression of p16 in gastric cancer cells. Oncol Rep 22: $1221-1227,2009$.

116. Watanabe Y, Toyota M, Kondo Y, Suzuki H, Imai T, Ohe-Toyota M, Maruyama R, Nojima M, Sasaki Y, Sekido Y, et al: PRDM5 identified as a target of epigenetic silencing in colorectal and gastric cancer. Clin Cancer Res 13: 4786-4794, 2007.

117. Cho HS, Shimazu T, Toyokawa G, Daigo Y, Maehara Y, Hayami S, Ito A, Masuda K, Ikawa N, Field HI, et al: Enhanced HSP70 lysine methylation promotes proliferation of cancer cells through activation of Aurora kinase B. Nat Commun 3: 1072, 2012.

118. Hamamoto R, Toyokawa G, Nakakido M, Ueda K and Nakamura Y: SMYD2-dependent HSP90 methylation promotes cancer cell proliferation by regulating the chaperone complex formation. Cancer Lett 351: 126-133, 2014

119. Huang J, Perez-Burgos L, Placek BJ, Sengupta R, Richter M, Dorsey JA, Kubicek S, Opravil S, Jenuwein T and Berger SL: Repression of p53 activity by Smyd2-mediated methylation. Nature 444: 629-632, 2006.
120. Saddic LA, West LE, Aslanian A, Yates JR III, Rubin SM, Gozani $\mathrm{O}$ and Sage J: Methylation of the retinoblastoma tumor suppressor by SMYD2. J Biol Chem 285: 37733-37740, 2010.

121. Cho HS, Hayami S, Toyokawa G, Maejima K, Yamane Y, Suzuki T, Dohmae N, Kogure M, Kang D, Neal DE, et al: RB1 methylation by SMYD2 enhances cell cycle progression through an increase of RB1 phosphorylation. Neoplasia 14: 476-486, 2012.

122. Piao L, Kang D, Suzuki T, Masuda A, Dohmae N, Nakamura Y and Hamamoto R: The histone methyltransferase SMYD2 methylates PARP1 and promotes poly(ADP-ribosyl)ation activity in cancer cells. Neoplasia 16: 257-264.e2., 2014.

123. Mazur PK, Reynoird N, Khatri P, Jansen PW, Wilkinson AW, Liu S, Barbash O, Van Aller GS, Huddleston M, Dhanak D, et al: SMYD3 links lysine methylation of MAP3K2 to Ras-driven cancer. Nature 510: 283-287, 2014.

124. Easwaran H, Tsai HC and Baylin SB: Cancer epigenetics: Tumor heterogeneity, plasticity of stem-like states, and drug resistance. Mol Cell 54: 716-727, 2014.

125. Compare D, Rocco A, Liguori E, D'Armiento FP, Persico G, Masone S, Coppola-Bottazzi E, Suriani R, Romano M and Nardone G: Global DNA hypomethylation is an early event in Helicobacter pylori-related gastric carcinogenesis. J Clin Pathol 64: 677-682, 2011

126. Yamashita S, Tsujino Y, Moriguchi K, Tatematsu M and Ushijima T: Chemical genomic screening for methylation-silenced genes in gastric cancer cell lines using 5-aza-2'-deoxycytidine treatment and oligonucleotide microarray. Cancer Sci 97: 64-71, 2006.

127. Sepulveda AR, Yao Y, Yan W, Park DI, Kim JJ, Gooding W, Abudayyeh S and Graham DY: CpG methylation and reduced expression of $O^{6}$-methylguanine DNA methyltransferase is associated with Helicobacter pylori infection. Gastroenterology 138: 1836-1844, 2010

128. Hur K, Niwa T, Toyoda T, Tsukamoto T, Tatematsu M, Yang HK and Ushijima T: Insufficient role of cell proliferation in aberrant DNA methylation induction and involvement of specific types of inflammation. Carcinogenesis 32: 35-41, 2011.

129. Nardone G, Rocco A and Malfertheiner P: Review article: Helicobacter pylori and molecular events in precancerous gastric lesions. Aliment Pharmacol Ther 20: 261-270, 2004.

130. Angrisano T, Lembo F, Peluso S, Keller S, Chiariotti L and Pero R: Helicobacter pylori regulates iNOS promoter by histone modifications in human gastric epithelial cells. Med Microbiol Immunol (Berl) 201: 249-257, 2012.

131. Han F, Ren J, Zhang J, Sun Y, Ma F, Liu Z, Yu H, Jia J and Li W: JMJD2B is required for Helicobacter pylori-induced gastric carcinogenesis via regulating COX-2 expression. Oncotarget 7: 38626-38637, 2016.

132. Bass AJ, Thorsson V, Shmulevich I, Reynolds SM, Miller M, Bernard B, Hinoue T, Laird PW, Curtis C, Shen H, et al; Cancer Genome Atlas Research Network: Comprehensive molecular characterization of gastric adenocarcinoma. Nature 513: 202-209, 2014

133. Kaneda A, Matsusaka K, Aburatani H and Fukayama M: Epstein-Barr virus infection as an epigenetic driver of tumorigenesis. Cancer Res 72: 3445-3450, 2012.

134. Sudo M, Chong JM, Sakuma K, Ushiku T, Uozaki H, Nagai H, Funata N, Matsumoto Y and Fukayama M: Promoter hypermethylation of E-cadherin and its abnormal expression in Epstein-Barr virus-associated gastric carcinoma. Int J Cancer 109: 194-199, 2004.

135. Osawa T, Chong JM, Sudo M, Sakuma K, Uozaki H, Shibahara J, Nagai H, Funata $\mathrm{N}$ and Fukayama M: Reduced expression and promoter methylation of p16 gene in EpsteinBarr virus-associated gastric carcinoma. Jpn J Cancer Res 93: 1195-1200, 2002.

136. Ryan JL, Jones RJ, Kenney SC, Rivenbark AG, Tang W, Knight ER, Coleman WB and Gulley ML: Epstein-Barr virusspecific methylation of human genes in gastric cancer cells. Infect Agent Cancer 5: 27, 2010.

137. Matsusaka K, Kaneda A, Nagae G, Ushiku T, Kikuchi Y, Hino R, Uozaki H, Seto Y, Takada K, Aburatani H, et al: Classification of Epstein-Barr virus-positive gastric cancers by definition of DNA methylation epigenotypes. Cancer Res 71: 7187-7197, 2011.

138. Ballestar E and Esteller M: SnapShot: The human DNA methylome in health and disease. Cell 135: 1144-1144.e1, 2008. 
139. Schneider BJ, Shah MA, Klute K, Ocean A, Popa E, Altorki NK, Lieberman MD, Schreiner A, Yantiss RK, Christos PJ, et al: Phase I study of epigenetic priming with azacitidine prior to standard neoadjuvant chemotherapy for patients with resectable gastric and esophageal adenocarcinoma. Clin Cancer Res doi: 10.1158/1078-0432.CCR-16-1896 (Epub ahead of print).

140. Liu J, Xie YS, Wang FL, Zhang LJ, Zhang Y and Luo HS: Cytotoxicity of 5-Aza-2'-deoxycytidine against gastric cancer involves DNA damage in an ATM-P53 dependent signaling pathway and demethylation of P16 $6^{\mathrm{INK} 4 \mathrm{~A}}$. Biomed Pharmacother 67: 78-87, 2013.

141. Shin DY, Kim GY, Kim CG, Kim WJ, Kang HS and Choi YH: Anti-invasive effects of decitabine, a DNA methyltransferase inhibitor, through tightening of tight junctions and inhibition of matrix metalloproteinase activities in AGS human gastric carcinoma cells. Oncol Rep 28: 1043-1050, 2012.

142. Tan W, Zhou W, Yu HG, Luo HS and Shen L: The DNA methyltransferase inhibitor zebularine induces mitochondria-mediated apoptosis in gastric cancer cells in vitro and in vivo. Biochem Biophys Res Commun 430: 250-255, 2013.

143. Takeshima H, Wakabayashi M, Hattori N, Yamashita S and Ushijima T: Identification of coexistence of DNA methylation and $\mathrm{H} 3 \mathrm{~K} 27 \mathrm{me} 3$ specifically in cancer cells as a promising target for epigenetic therapy. Carcinogenesis 36: 192-201, 2015.

144. Cheng LL, Itahana Y, Lei ZD, Chia NY, Wu Y, Yu Y, Zhang SL, Thike AA, Pandey A, Rozen S, et al: TP53 genomic status regulates sensitivity of gastric cancer cells to the histone methylation inhibitor 3-deazaneplanocin A (DZNep). Clin Cancer Res 18: 4201-4212, 2012

145. Kaminskas E, Farrell AT, Wang YC, Sridhara R and PazdurR: FDA drug approval summary: Azacitidine (5-azacytidine, Vidaza) for injectable suspension. Oncologist 10: 176-182, 2005.

146. Steensma DP, Baer MR, Slack JL, Buckstein R, Godley LA, Garcia-Manero G, Albitar M, Larsen JS, Arora S, Cullen MT, et al: Multicenter study of decitabine administered daily for 5 days every 4 weeks to adults with myelodysplastic syndromes: The alternative dosing for outpatient treatment (ADOPT) trial. J Clin Oncol 27: 3842-3848, 2009.

147. Erdmann A, Halby L, Fahy J and Arimondo PB: Targeting DNA methylation with small molecules: What's next? J Med Chem 58 2569-2583, 2015

148. Navada SC, Steinmann J, Lübbert M and Silverman LR: Clinical development of demethylating agents in hematology. J Clin Invest 124: 40-46, 2014.

149. Chen XL, Wang FM, Li JJ, He XY, Liu XY and Ma LB: The effect of two nucleoside antitumor drugs on the proliferation and DNA methylation of human gastric cancer cells. Oncol Lett 10 : 1919-1923, 2015.

150. Karahoca M and Momparler RL: Pharmacokinetic and pharmacodynamic analysis of 5-aza-2'-deoxycytidine (decitabine) in the design of its dose-schedule for cancer therapy. Clin Epigenetics 5: 3, 2013.

151. Si J, Boumber YA, Shu J, Qin T, Ahmed S, He R, Jelinek J and Issa JP: Chromatin remodeling is required for gene reactivation after decitabine-mediated DNA hypomethylation. Cancer Res 70: 6968-6977, 2010.

152. Plumb JA, Strathdee G, Sludden J, Kaye SB and Brown R: Reversal of drug resistance in human tumor xenografts by 2'-deoxy-5-azacytidine-induced demethylation of the hMLH1 gene promoter. Cancer Res 60: 6039-6044, 2000

153. Wu FL, Li RT, Yang M, Yue GF, Wang HY, Liu Q, Cui FB, Wu PY, Ding H, Yu LX, et al: Gelatinases-stimuli nanoparticles encapsulating 5-fluorouridine and 5-aza-2'-deoxycytidine enhance the sensitivity of gastric cancer cells to chemical therapeutics. Cancer Lett 363: 7-16, 2015.
154. Chen M, Shabashvili D, Nawab A, Yang SX, Dyer LM, Brown KD, Hollingshead M, Hunter KW, Kaye FJ, Hochwald SN, et al: DNA methyltransferase inhibitor, zebularine, delays tumor growth and induces apoptosis in a genetically engineered mouse model of breast cancer. Mol Cancer Ther 11: 370-382, 2012

155. Ben-Kasus T, Ben-Zvi Z, Marquez VE, Kelley JA and Agbaria R: Metabolic activation of zebularine, a novel DNA methylation inhibitor, in human bladder carcinoma cells. Biochem Pharmacol 70: $121-133,2005$

156. Plass C, Pfister SM, Lindroth AM, Bogatyrova O, Claus R and Lichter P: Mutations in regulators of the epigenome and their connections to global chromatin patterns in cancer. Nat Rev Genet 14: 765-780, 2013

157. Greiner D, Bonaldi T, Eskeland R, Roemer E and Imhof A Identification of a specific inhibitor of the histone methyltransferase SU(VAR)3-9. Nat Chem Biol 1: 143-145, 2005.

158. Glazer RI, Hartman KD, Knode MC, Richard MM, Chiang PK, Tseng CK and Marquez VE: 3-Deazaneplanocin: A new and potent inhibitor of S-adenosylhomocysteine hydrolase and its effects on human promyelocytic leukemia cell line HL-60. Biochem Biophys Res Commun 135: 688-694, 1986.

159. Tan J, Yang X, Zhuang L, Jiang X, Chen W, Lee PL, Karuturi RK, Tan PB, Liu ET and Yu Q: Pharmacologic disruption of Polycomb-repressive complex 2-mediated gene repression selectively induces apoptosis in cancer cells. Genes Dev 21: 1050-1063, 2007.

160. Sun F, Lee L, Zhang Z, Wang X, Yu Q, Duan X and Chan E: Preclinical pharmacokinetic studies of 3-deazaneplanocin A, a potent epigenetic anticancer agent, and its human pharmacokinetic prediction using GastroPlus ${ }^{\mathrm{TM}}$. Eur J Pharm Sci 77: 290-302, 2015

161. McCabe MT, Ott HM, Ganji G, Korenchuk S, Thompson C, Van Aller GS, Liu Y, Graves AP, Della Pietra A III, Diaz E, et al: $\mathrm{EZH} 2$ inhibition as a therapeutic strategy for lymphoma with EZH2-activating mutations. Nature 492: 108-112, 2012.

162. Chen YT, Zhu F, Lin WR, Ying RB, Yang YP and Zeng LH: The novel EZH2 inhibitor, GSK126, suppresses cell migration and angiogenesis via down-regulating VEGF-A. Cancer Chemother Pharmacol 77: 757-765, 2016.

163. Knutson SK, Warholic NM, Wigle TJ, Klaus CR, Allain CJ, Raimondi A, Porter Scott M, Chesworth R, Moyer MP, Copeland RA, et al: Durable tumor regression in genetically altered malignant rhabdoid tumors by inhibition of methyltransferase EZH2. Proc Natl Acad Sci USA 110: 7922-7927, 2013

164. Qi W, Chan H, Teng L, Li L, Chuai S, Zhang R, Zeng J, Li M Fan H, Lin Y, et al: Selective inhibition of Ezh2 by a small molecule inhibitor blocks tumor cells proliferation. Proc Natl Acad Sci USA 109: 21360-21365, 2012.

165. Bai J, Ma M, Cai M, Xu F, Chen J, Wang G, Shuai X and Tao K: Inhibition enhancer of zeste homologue 2 promotes senescence and apoptosis induced by doxorubicin in p53 mutant gastric cancer cells. Cell Prolif 47: 211-218, 2014.

166. Lee MG, Wynder C, Schmidt DM, McCafferty DG and Shiekhattar R: Histone H3 lysine 4 demethylation is a target of nonselective antidepressive medications. Chem Biol 13: 563-567, 2006.

167. Schmidt DM and McCafferty DG: trans-2-Phenylcyclopropylamine is a mechanism-based inactivator of the histone demethylase LSD1. Biochemistry 46: 4408-4416, 2007. 